\title{
A Double-edged Sword: Transformational Leadership and Individual Creativity
}

\author{
Silke Astrid Eisenbeiß and Sabine Boerner ${ }^{1}$ \\ Ludwig-Maximilians-University, Munich, Germany, and ${ }^{1}$ University of Konstanz, Konstanz, Germany \\ Email: silke_eisenbeiss@hotmail.com; sabine.boerner@uni-konstanz.de
}

\begin{abstract}
Leadership research has focused on the positive effects of transformational and charismatic leadership but has neglected the negative side effects. Addressing this gap, we analysed followers' dependency on the leader as a relevant negative side effect in the relationship between transformational leadership and followers' creativity and developed an integrative framework on parallel positive and negative effects of transformational leadership. As expected, results from a study with $416 \mathrm{R} \& D$ employees showed that transformational leadership promotes followers' creativity but at the same time increases followers' dependency which in turn reduces their creativity. This negative indirect effect attenuates the positive influence of transformational leadership on followers' creativity.
\end{abstract}

\section{Introduction}

Transformational leadership has fundamentally shaped the last decades in leadership research and become quite popular in organizations, as indicated by the spreading use of transformational leadership trainings and education (Avolio, 1999; Bass and Riggio, 2006; Tourish, Craig and Amernic, 2010). Originally introduced by Burns (1978) and further developed by Bass (1985), the concept of transformational leadership has found unique acceptance in the literature on management (Antonakis and House, 2002; Lowe and Gardner, 2000). Several meta-analyses confirmed that transformational leadership can positively influence followers' performance and satisfaction across various organizational settings and different cultures (DeGroot, Kiker and Cross, 2000; Dumdum, Lowe and Avolio, 2002; Lowe, Kroeck and Sivasubramaniam, 1996; Patterson et al., 1995).

In particular, transformational leaders are expected to intellectually stimulate their followers

We are very grateful to Felix C. Brodbeck for his helpful comments on an earlier version of this paper. and thus may activate the followers' creativity potential (Avolio, 1994; Bass and Riggio, 2006; Conger and Kanungo, 1992). Accordingly, Cascio (1995, p. 930) pointed out: 'Today's networked, interdependent, culturally diverse organizations require transformational leadership ... to transform followers to bring out their creativity, imagination, and best efforts'. Yet, empirical evidence is still mixed, including positive (Gong, Huang and Farh, 2009; Shin and Zhou, 2003), negative (Basu and Green, 1997) and non-significant direct relationships (Jaussi and Dionne, 2003; Wang and Rode, 2010) between transformational leadership and followers' creativity.

In order to contribute to the body of empirical research on transformational leadership and individual creativity and to help address the issue of a confusing pattern of results, we argue that negative side effects of transformational leadership such as raising followers' dependency may be of importance. Although some authors have touched upon the negative side effects of transformational and charismatic leadership (Beyer, 1999; Bryman, 1992; Yukl, 1999), most previous research has neglected this topic.

Addressing this research gap, this paper develops and empirically tests a theoretical framework 
which comprises both positive and negative effects of transformational leadership on followers' creativity. By analysing the 'black box' between transformational leadership and followers' creativity and integrating positive and negative effects of transformational leadership, we aim to provide a deeper understanding of how transformational leadership works and what risks it may imply.

More precisely, we argue that transformational leadership has two parallel effects. On the one hand, transformational leaders are assumed to influence followers' creativity positively, because they provide them with intellectual stimulation and serve as role models for unconventional behaviour and an original thinking style. On the other hand and particularly due to their charisma and their narcissistic tendencies, transformational leaders are also likely to promote followers' dependency which in turn may have a negative impact on followers' creativity. This negative side effect of transformational leadership via an increase in followers' dependency is expected to attenuate the positive influence of transformational leadership on followers' creativity.

\section{Theoretical background}

\section{Transformational leadership theory}

Based on Burns's (1978) seminal work, Bass (1985) transferred the distinction between transactional and transforming political leadership into the organizational context and developed the full range of leadership theory (see Bass and Avolio, 1994). According to this comprehensive theoretical framework, transformational leaders 'motivate people to do their best' (Avolio and Bass, 1988, p. 33) and make their followers perform beyond expectations by moving them to overcome their self-interest to strive for a higher purpose or vision (Bass, 1985; Bass and Riggio, 2006).

Bass (1985, 1998) characterized transformational leadership as comprising four components. Idealized influence (or charisma) can be defined as influence on ideals, values and 'bigger-than-life' issues and refers to role model behaviour of transformational leaders and their attributed extraordinary personal qualities. Inspirational motivation refers to leadership behaviour such as providing meaning to followers' work and articulating an appealing or evocative vision for the team or the organization. Intellectual stimulation means that transformational leaders encourage followers to challenge existing assumptions, reframe problems and approach situations in new ways. Individualized consideration relates to coaching and mentoring behaviour of transformational leaders that take individual differences between followers into account.

Pointing to the similarity between transformational and charismatic leadership, several authors (e.g. den Hartog et al., 1999; Shamir, House and Arthur, 1993) treated the two leadership concepts as synonyms. However, Bass and Riggio (2006, p. 5) explicitly noted: 'Transformational leadership has much in common with charismatic leadership, but charisma is only part of transformational leadership.' The present paper follows this argumentation but will use both transformational and charismatic leadership theories to explain the influence of transformational leadership on followers' creativity.

\section{The positive impact of transformational leadership on followers' creativity}

Transformational leadership differs from traditional leadership styles as it is more about emphasizing change and envisioning (Avolio, 1994; Conger and Kanungo, 1992) than about focusing on supervision, monitoring and control (Bryman, 1992). Hence, transformational leadership theory is regarded as potentially increasing creativity and innovation (García-Morales, Lloréns-Montes and Verdú-Jover, 2008; Waldman and Bass, 1991).

Creativity refers to 'the production of novel and useful ideas by an individual or small group of individuals working together' (Amabile, 1988, p. 126) and can be interpreted as the idea generation component of innovation (Rank, Pace and Frese, 2004). As innovation comprises both developing and implementing these ideas, creativity often is regarded as the first phase of the innovation process (Amabile, 1988; Anderson, de Dreu and Nijstad, 2004; Paulus, 2002; Pirola-Merlo and Mann, 2004).

Transformational leaders are assumed to promote followers' creativity via two mechanisms: a cognitive and a motivational mechanism (Gebert, 2002). On the cognitive level, transformational leadership mainly works through the intel- 
lectual stimulation component (Waldman and Bass, 1991). Transformational leaders point out unconventional perspectives, break away from common patterns of thought and encourage their followers to critically appraise and reflect on existing assumptions and working methods (Bass, 1985). Furthermore, they encourage their subordinates to adopt an explorative and open mindset and to think 'out of the box' (Jung, Chow and $\mathrm{Wu}, 2003)$. Thereby, followers are assumed to rediscover their intellectual curiosity, use their imagination and generate original solutions and fresh and unique ideas (Avolio, Bass and Jung, 1999; Bass, 1985). Moreover, transformational leaders display unconventional and creative behaviour themselves and thus serve as a role model for creativity. According to social learning theory (Bandura, 1998), followers are likely to emulate a transformational leader and therefore engage in creative behaviour themselves.

The motivational mechanism relates to the visionary component of transformational leadership. Transformational leaders tend to act as 'change agents' by stressing the shortcomings of the status quo, highlighting aspects for improvement and envisioning attractive and desirable future states with which the followers can identify (Avolio, 1994). However, developing a promising vision for the future does not seem to be a sufficient condition to promote followers' creativity. Followers also have to perceive themselves as capable of altering the status quo. Transformational leaders have been shown to increase followers' self-efficacy (Pillai and Williams, 2004). By inspiring followers with their passion, drive and self-assurance and by consistently communicating positive result expectancies, transformational leaders underpin followers' willingness to work on improving the status quo, even if this may involve difficulties and uncertainty (Conger and Kanungo, 1998; Kirkpatrick and Locke, 1996; Shamir, House and Arthur, 1993). Hence, under transformational leadership, followers are assumed to experience differences between a desired future state and a given situation less as a threat than as a challenge that raises their creativity and their effort.

H1: Transformational leadership is positively related to followers' creativity.

\section{Mixed findings on transformational leadership and followers' creativity}

However, although the theoretical argumentation outlined above points toward a positive relationship between transformational leadership and followers' creativity, the empirical evidence is mixed, including positive, negative and non-significant relationships between transformational leadership and followers' creative and innovative behaviour (see Table 1).

Using a qualitative study design, Howell and Higgins (1990) were the first to empirically examine the relationship between transformational leadership and creativity and innovation. Their results indicate a positive relationship as they found that so-called champions of techno-

Table 1. Empirical studies on the relationship between transformational leadership and followers' creativity

\begin{tabular}{|c|c|c|c|c|c|}
\hline Author & $\begin{array}{c}\text { Year of } \\
\text { publication }\end{array}$ & Design & Sample & Dependent variable & Result \\
\hline $\begin{array}{c}\text { Howell and } \\
\text { Higgins }\end{array}$ & 1990 & $\begin{array}{l}\text { Qualitative field } \\
\text { study }\end{array}$ & 50 leaders & Not defined & $\begin{array}{l}\text { Innovation champions display } \\
\text { transformational leadership } \\
\text { significantly more frequently } \\
\text { than non-champions }\end{array}$ \\
\hline $\begin{array}{l}\text { Basu and } \\
\text { Green }\end{array}$ & 1997 & $\begin{array}{l}\text { Quantitative field } \\
\text { study }\end{array}$ & $\begin{array}{l}225 \text { leader-follower } \\
\text { dyads }\end{array}$ & $\begin{array}{l}\text { Followers' innovative } \\
\text { behaviour (leader rating) }\end{array}$ & $\begin{array}{l}\text { Significant negative } \\
\text { relationship }\end{array}$ \\
\hline $\begin{array}{l}\text { Shin and } \\
\text { Zhou }\end{array}$ & 2003 & $\begin{array}{l}\text { Quantitative field } \\
\text { study }\end{array}$ & $\begin{array}{l}290 \text { leader-follower } \\
\text { dyads }\end{array}$ & $\begin{array}{l}\text { Followers' creativity (leader } \\
\text { rating) }\end{array}$ & $\begin{array}{l}\text { Significant positive } \\
\text { relationship }\end{array}$ \\
\hline $\begin{array}{c}\text { Jaussi and } \\
\text { Dionne }\end{array}$ & 2003 & $\begin{array}{l}\text { Quantitative } \\
\text { experiment }\end{array}$ & 364 students & $\begin{array}{l}\text { Followers' creativity } \\
\text { (independent observer rating) }\end{array}$ & $\begin{array}{l}\text { Non-significant direct } \\
\text { relationship }\end{array}$ \\
\hline $\begin{array}{l}\text { Gong, Huang } \\
\text { and Farh }\end{array}$ & 2009 & $\begin{array}{l}\text { Quantitative field } \\
\text { study }\end{array}$ & $\begin{array}{l}111 \text { leaders and } 200 \\
\text { employees }\end{array}$ & $\begin{array}{l}\text { Followers' creativity (leader } \\
\text { rating) }\end{array}$ & $\begin{array}{l}\text { Significant positive } \\
\text { relationship }\end{array}$ \\
\hline $\begin{array}{l}\text { Wang and } \\
\text { Rode }\end{array}$ & 2010 & $\begin{array}{l}\text { Quantitative field } \\
\text { study }\end{array}$ & $\begin{array}{l}71 \text { leaders and } 212 \\
\text { employees }\end{array}$ & $\begin{array}{l}\text { Followers' creativity (leader } \\
\text { rating) }\end{array}$ & $\begin{array}{l}\text { Non-significant direct } \\
\text { relationship }\end{array}$ \\
\hline
\end{tabular}


logical innovation engage in transformational leadership behaviour more frequently than nonchampions. Accordingly, in a quantitative study with 290 employees and their supervisors from 46 Korean firms, Shin and Zhou (2003) found that transformational leaders promoted their followers' creativity and that intrinsic motivation partially mediated this relationship. In agreement, Gong, Huang and Farh (2009) showed that transformational leadership was positively related to employee creativity in the insurance industry.

However, examining 225 leader-member dyads in a manufacturing plant, Basu and Green (1997) reported a negative relationship between transformational leadership and followers' innovative behaviour. To make the state of empirical evidence even more complex, Jaussi and Dionne (2003), who studied the influence of transformational leaders on creative performance in an experimental setting, could not find any significant relationship at all. And in a study of 55 organizations, Wang and Rode (2010) did not find a significant direct link between transformational leadership and employee creativity either.

That mixed pattern of findings cannot be explained by different conceptualizations and operationalizations of the creativity construct in the extant studies. For instance, Shin and Zhou (2003), Gong, Huang and Farh (2009) and Wang and Rode (2010) all referred to Amabile's (1988) definition of creativity and measured creativity via similar scales relating to the production of novel ideas by an individual. However, despite this commonality, Wang and Rode (2010) could not confirm the positive link between transformational leadership and creativity found in both of the other studies.

\section{The negative impact of transformational leadership on followers' creativity}

Shedding light on negative side effects of transformational leadership may help explain the mixed picture of empirical findings. Beyer (1999) and Yukl (1999) stressed that negative effects of transformational and charismatic leadership have hitherto been neglected and deserve further research. Addressing this demand, we argue that we will not fully understand the relationship between transformational leadership and followers' creativity unless negative side effects of transformational leadership are considered. We focus on follower dependency as a negative side effect of transformational leadership, because previous literature referred to it as the most elementary side effect of high transformational and charismatic leadership (see Conger and Kanungo, 1998). Moreover, it assumedly plays a significant role in the transformational leadership-creativity link (Basu and Green, 1997). To explain their unexpected finding of a negative relationship between transformational leadership and follower innovativeness, Basu and Green (1997) referred to the mediating mechanism of follower dependency. They argued that transformational leaders may censor followers' critical and non-conformal viewpoints and ideas that differ from their own, thereby triggering follower dependency and limiting innovativeness.

According to Birtchnell (1988, p. 111), a dependent person 'receives from others a borrowed identity, guidance and direction, compensation for those areas in which he is incompetent and, most important of all, acceptance, approval and affirmation of worth'. Some charismatic leadership theories mention that this form of leadership may increase followers' dependency on their leader (Conger, 1990; Yuk1, 1998).

Psychoanalytic theories explain the development of dependency by tracing it back to the parent-child relationship and by using the concepts of transference and projection (Kets de Vries, 1988). From the perspective of small children, parents seem to be omnipotent and perfect and thus make them feel protected and secure. As the feelings of absolute protection ebb during adolescence, the - often unconscious - desire remains to recreate this state. By providing guidance, developing a comprehensive and attractive vision for the future and forming strong role models, transformational and charismatic leaders may be able to recreate this state for their followers (Popper and Mayseless, 2003). As they give focus for others and become creators of meaning, they can offer a sort of salvation to their followers (e.g. in the form of safety, identity or rituals) (Kets de Vries, 1988).

Transference is a universal phenomenon and refers to a false relationship or a 'modified version of an old relationship' (see Kets de Vries, 1988 , p. 270). The follower perceives and responds to the leader as if he/she were a parent 
or some other important figure from the past who is stronger and more capable (Conger and Kanungo, 1998; Kets de Vries and Miller, 1984; Steyrer, 1999). Projection is an attributional process through which leaders become the recipients (or 'basins') of their followers' ideals, desires and fantasies. Facing ambiguous and uncertain situations, followers tend to seek leaders who assume responsibility and turn chaos into order. In accepting this role, these leaders raise their followers' trust, identification and admiration and may become idols and role models for values, beliefs and behavioural norms (Gardner and Avolio, 1998; Kark, Shamir and Chen, 2003). Yukl (1999) further pointed out that these leaders - either unconsciously or consciously can exploit followers by producing exceedingly high levels of emotional engagement and attachment. As a result, followers are likely to become dependent on their leader and his/her ideas, desires and visions.

Leaders' narcissistic tendencies may even aggravate this process (Hogan, Raskin and Fazzini, 1990; Kets de Vries, 1988). House and Howell (1992) showed that narcissism is closely related to certain characteristics of charismatic leaders. Narcissistic leaders tend to deny their negative personal characteristics, to overestimate their abilities and to reject critical comments on their ideas or their visions (Conger and Kanungo, 1998; Shamir, 1991).

In this context, it appears to be relevant that Bass and Steidlmeier (1999, p. 186) differentiate between authentic and pseudo-transformational leadership: 'It is the presence or absence of such a moral foundation of the leader as a moral agent that grounds the distinction between authentic versus pseudo-transformational leadership'. Similarly, Howell (1988) distinguishes between personalized and socialized charisma and Howell and Avolio (1992) differentiate between ethical and unethical leaders. All these dichotomous approaches share the idea that transformational and charismatic leaders who have moral intentions and elaborated value systems have to be clearly distinguished from leaders who mainly pursue their personal interests, who try to increase their own power and who do not respect their followers' needs and wishes but insist on obedience. Whereas some scholars argued that follower dependency may occur particularly under unethical forms of transformational and charismatic leadership (Bass, 1998; Howell, 1988), de Vries, Roe and Taillieu (1999) pointed out that followers' dependency may also increase under authentic transformational leadership.

Reviewing the empirical research literature on transformational leadership, we surprisingly found only one study which dealt with the relationship between transformational leadership and dependency. Kark, Shamir and Chen (2003) found that transformational leadership increases followers' dependency and that followers' personal identification with the leader mediates this relationship. However, they did not investigate what effect follower dependency may have on outcome variables of organizational interest (e.g. performance and creativity) but called for further research in this field.

Addressing this call, we argue that follower dependency influences creativity negatively via both cognitive and motivational processes. First, followers' dependency may inhibit their creativity, because followers' strong admiration of and attachment to the leader may cause uncritical acceptance of the leader's ideas and unconditional cognitive allegiance (Basu and Green, 1997; Gebert, 2002). As a result, followers may be less likely to develop unconventional ideas themselves, to seek 'out-of-the-box' solutions and to break open established thinking patterns. Second, from a motivational perspective, followers' dependency may make them strongly seek the leader's recognition and approval (Conger, 1990). As a consequence, they are less likely to openly express doubts and critical thoughts which may alienate the leader. Further, the leader's absence (e.g. illness or vacation) can lead to feelings of disorientation among the followers (Shamir, 1991) and thereby negatively diminish their engagement, willingness to perform and creativity.

To sum up, we expect that the positive influence of transformational leadership on followers' creativity (see Hypothesis 1) will be attenuated by the negative side effect of transformational leadership - i.e. an increasing level of followers' dependency (Hypotheses 2, 3 and 4). Figure 1 illustrates our theoretical framework on the relationship between transformational leadership, followers' dependency and their creativity.

H2: Transformational leadership is positively related to follower dependency. 


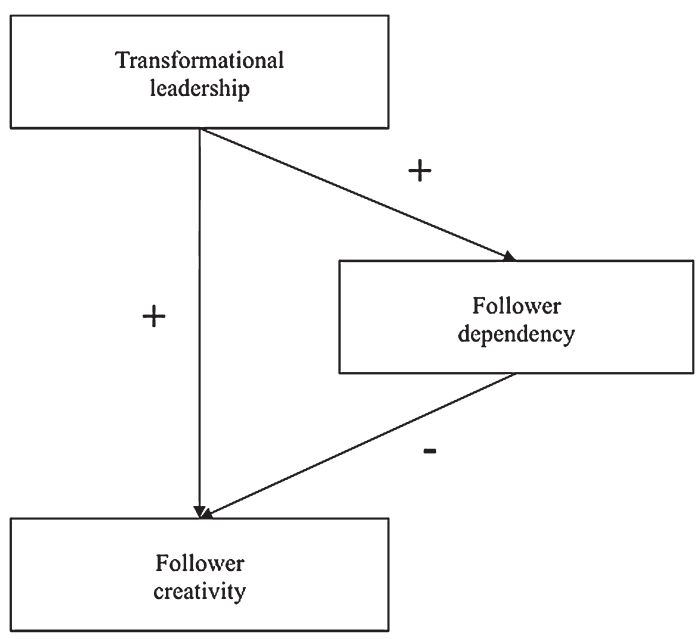

Figure 1. Theoretical model of the relationship between transformational leadership, followers' dependency and their creativity

H3: Follower dependency is negatively related to their creativity.

H4: Transformational leadership is negatively related to follower creativity via follower dependency.

\section{Method}

\section{Research setting and procedure}

We contacted 73 industrial enterprises engaged in R\&D-oriented sectors and three research institutes in Germany, all with more than a thousand employees, and asked them to participate in the present study. Participation meant that some of the organization's R\&D employees would have to answer a web-based survey. In most cases, we contacted the innovation vice-president of the organization, the chief officer of the R\&D department or the head of the human resources department. The organizational contact persons received information about the study's objectives and - as an incentive to participate - were promised a presentation of the study's main findings, a company-specific data analysis, an anonymous benchmarking with organizations operating in a comparable sector and some recommendations for improving their creativity management upon completion of the study. Anonymous and strictly confidential data treatment was assured. Thirteen companies and one research institute agreed to participate in the study, corresponding to a participation quota of $18.21 \%$.

To launch the survey, we gave the organizational contact persons the link to the website and asked them to pass on the provided information to the respective employees and encourage them to participate. We asked the R\&D employees about their perception of their team leader's transformational leadership, their own level of dependency on the leader and their individual creativity.

\section{Sample}

In total, $416 \mathrm{R} \& \mathrm{D}$ employees from one research institute and 11 international companies, mainly based in Germany and working in the high-tech, medical engineering, electronics, semiconductor, software, chemistry or biology industries, participated in the study. The employees were primarily men $(75.1 \%)$ between 24 and 58 years of age, the average age being 37 and average number of years with the company 8.7 years.

\section{Measures}

Transformational leadership. We measured transformational leadership by using a 20-item scale of Bass and Avolio's (1995) Multifactor Leadership Questionnaire (MLQ), translated into German by Felfe (2006). The MLQ, which is regarded as the most common measure of transformational leadership (Judge and Piccolo, 2004; Yuk1, 1998), assesses the five sub-components of transformational leadership via four items each (i.e. idealized influence attributed, idealized influence behaviour, inspirational motivation, intellectual stimulation, individual consideration). The items were rated on a seven-point scale ranging from 1 (never) to 7 (almost always). A sample item was 'The leader gets me to look at problems from many different angles'.

To evaluate the factor structure of our measure of transformational leadership, we used confirmatory factor analyses with AMOS 18 to test a two-level model. Following Bass's (1985) understanding of transformational leadership, this model contained the sub-components of transformational leadership as five different factors at the first level and transformational leadership as an underlying single factor at the second level. The results showed support for the expected two-level 
Table 2. Rotated principal components matrix for the measure of followers' dependency

\begin{tabular}{|c|c|c|c|c|c|c|}
\hline \multicolumn{2}{|l|}{ Item } & \multirow{2}{*}{$\begin{array}{c}\text { Factor } 1 \\
0.162\end{array}$} & \multirow{2}{*}{$\begin{array}{c}\text { Factor } 2 \\
\mathbf{0 . 5 6 9}\end{array}$} & \multirow{2}{*}{$\begin{array}{l}\text { Factor } 3 \\
-0.209\end{array}$} & \multirow{2}{*}{$\begin{array}{c}\text { Factor } 4 \\
0.019\end{array}$} & \multirow{2}{*}{$\begin{array}{r}\text { Factor } 5 \\
0.030\end{array}$} \\
\hline Item 1: & $\begin{array}{l}\text { I feel I can function well at work, irrespective of who is the direct } \\
\text { supervisor }\end{array}$ & & & & & \\
\hline Item 2: & I find it difficult to function without my direct supervisor's guidance & 0.112 & 0.763 & 0.194 & -0.031 & 0.062 \\
\hline Item 3: & I feel I can do my job better when my direct supervisor is around & 0.093 & 0.746 & 0.091 & 0.168 & -0.030 \\
\hline Item 4: & $\begin{array}{l}\text { If my direct supervisor were replaced, I would feel I do not have anyone } \\
\text { to give me advice }\end{array}$ & 0.564 & 0.443 & 0.197 & 0.032 & 0.074 \\
\hline Item 5: & I don't question my direct supervisor's orders & 0.208 & -0.111 & 0.758 & 0.067 & -0.012 \\
\hline Item 6: & I accept my direct supervisor's viewpoints and do not challenge them & 0.085 & 0.075 & 0.841 & 0.013 & -0.014 \\
\hline Item 7: & $\begin{array}{l}\text { Before carrying out my direct supervisor's orders I think over if they are } \\
\text { reasonable }\end{array}$ & -0.191 & 0.171 & 0.554 & -0.113 & 0.161 \\
\hline Item 8: & $\begin{array}{l}\text { If my direct supervisor were to leave, my commitment to work would } \\
\text { decline }\end{array}$ & 0.904 & 0.139 & 0.006 & 0.061 & 0.164 \\
\hline Item 9: & If my direct supervisor were to leave, my motivation would decline & 0.922 & 0.143 & 0.024 & 0.035 & 0.099 \\
\hline Item 10: & $\begin{array}{l}\text { When my direct supervisor goes on vacation, my readiness to work } \\
\text { overtime decreases }\end{array}$ & 0.186 & -0.042 & 0.081 & 0.098 & 0.848 \\
\hline Item 11: & $\begin{array}{l}\text { When my direct supervisor goes on vacation, my enthusiasm for work } \\
\text { deteriorates }\end{array}$ & 0.075 & 0.099 & 0.015 & 0.093 & 0.881 \\
\hline Item 12: & $\begin{array}{l}\text { At work it is important for me to receive praise from my direct } \\
\text { supervisor }\end{array}$ & 0.042 & 0.060 & -0.015 & 0.902 & 0.045 \\
\hline Item 13: & At work I strive to win my direct supervisor's recognition & 0.049 & 0.081 & -0.005 & 0.885 & 0.145 \\
\hline
\end{tabular}

factor structure, $\chi^{2} / \mathrm{df}=3.596$, the confirmatory fit index $(\mathrm{CFI})=0.928$ and the root-mean-square error of approximation $(\mathrm{RMSEA})=0.079$. The reliabilities of the sub-scales for transformational leadership were satisfying, with Cronbach's alpha $=0.868$ for idealized influence attributed, 0.835 for idealized influence behaviour, 0.872 for inspirational motivation, 0.867 for intellectual stimulation and 0.895 for individual consideration. The reliability analysis on the overall scale for transformational leadership showed good results as well (Cronbach's alpha $=0.954)$.

Followers' dependency. To measure followers' dependency, based on Kark, Shamir and Chen's (2003) measure of dependency, we further developed the scale in order to fully cover both the cognitive and the motivational aspects of the construct. Specifically, we selected six items from Kark, Shamir and Chen's (2003) scale that referred either to the cognitive (four items) or the motivational (two items) aspect and translated them into German via the back-translation method (see Brislin, 1986). Another seven items were generated by reviewing the social scientific leadership literature regarding statements on follower dependency (Bass and Steidlmeier, 1999; Beyer, 1999; Bryman, 1992; Conger, 1990, 1999; Conger and Kanungo, 1998; Gebert, 2002; Howell, 1988; Howell and Avolio, 1992; Kark and
Shamir, 2002; Yuk1, 1999). Items were rated on a seven-point scale ranging from 1 (totally disagree) to 7 (totally agree).

To determine the factor structure of our measure of follower dependency, we first conducted a principal components analysis with varimax rotation. Based on the Kaiser-Guttman criterion (Guttman, 1954), we extracted five factors, explaining $68.583 \%$ of variance (see Table 2). Factor 1 relates to followers' dependency regarding their work motivation; factor 2 to followers' dependency on the leader's technical expertise and guidance; factor 3 to followers' uncritical acceptance of the leader's ideas and assignments; factor 4 to followers' dependency on the leader regarding their work engagement; and factor 5 to followers' striving for approval. Hence, factors 2 and 3 represent cognitive components of followers' dependency and factors 1, 4 and 5 relate to motivational components.

For further validation, we subsequently conducted a confirmatory factor analysis, testing if the five first-order factors loaded on one secondorder factor - namely, overall followers' dependency on the leader. Then, we compared this hierarchical two-level model with two alternatives: first, a model comprising the cognitive and the motivational component of follower dependency as two separate factors; second, a simple one-factor model. As expected, the results clearly 
Table 3. Tested models of followers' dependency

\begin{tabular}{lccccccr}
\hline Model & $\chi^{2}$ & $\mathrm{df}$ & $\mathrm{p}$ & $\chi^{2} / \mathrm{df}$ & $\mathrm{RMSEA}$ & $\mathrm{CFI}$ & TLI \\
\hline $\begin{array}{l}\text { Model 1: Hierarchical model with five first-order } \\
\quad \text { factors and one second-order factor }\end{array}$ & 132.823 & 60 & 0.000 & 2.214 & 0.055 & 0.951 & 0.936 \\
$\begin{array}{l}\text { Model 2: Two-factor model } \\
\text { Model 3: One-factor model }\end{array}$ & 630.723 & 64 & 0.000 & 9.855 & 0.148 & 0.618 & 0.534 \\
\hline
\end{tabular}

TLI, Tucker-Lewis index.

supported the hierarchical model, $\chi^{2} / \mathrm{df}=2.214$, CFI $=0.951$, RMSEA $=0.055$ (see also Table 3 ). The reliability analysis of the scale on follower dependency also showed acceptable results (Cronbach's alpha $=0.705$ ).

Followers' creativity. We measured followers' creativity via ten items from Zhou and George's (2001) scale of individual creativity. Designed to operationalize Amabile's (1988) definition of creativity which our paper builds on this scale has been used in previous work on transformational leadership and creativity (Shin and Zhou, 2003). We reworded the items to make them first-person statements and then translated them into German using the back-translation method (Brislin, 1986). A sample item was 'I suggest new ways to achieve goals or objectives'. Items were rated on a sevenpoint scale ranging from 1 (totally disagree) to 7 (totally agree). To test the validity of the adapted scale, we conducted a principal components analysis. As expected, only one factor was extracted, explaining $52.637 \%$ of variance. Cronbach's alpha was 0.894, indicating satisfying reliability.

Control variable. We assessed followers' individual team longevity as a control variable because it may affect creativity. With longer team membership, followers become increasingly accustomed to the team's mode of operation (the procedures, practices and norms established in the team) (West, 2003), tend to communicate less internally as well as externally and tend to dissociate themselves from independent external information sources (Katz, 1982). With time, they may become less likely to question the status quo and to engage in 'out of the box' thinking: the results are reduced levels of originality and creativity. In addition, team cohesion and conformity pressure may increase with rising team longevity and thereby further aggravate the described process of uncritical acceptance and reduced cognitive flexibility (Mullen et al., 1994). Previous research showed that tenure can negatively influence individual creativity (Chusmir and Koberg, 1986). We measured individual team longevity via the number of months the individual had been working on the respective team.

\section{Analysis}

Subsequently, we tested the model presented in Figure 1 using structural equation modelling, thereby also testing for discriminative validity between the constructs of the study. As is common in management and organizational behaviour research (e.g. Carlson, Kacmar and Williams, 2000), we used $\chi^{2} / \mathrm{df}$, the CFI and the RMSEA to evaluate model fit. The different foci of the three fit indices complement each other well. Whereas $\chi^{2}$ and $\chi^{2} / \mathrm{df}$ assess the extent to which the covariance matrix estimated by the hypothesized model reproduces the observed matrix, the CFI measures the model fit with regard to the worst and best fit attainable and also accounts for population parameters. The RMSEA indicates the amount of error present in the model (see Bentler, 1980, 1990; Kline, 1998).

As our preliminary data analyses showed that both transformational leadership and follower dependency were complex multidimensional constructs with a hierarchical structure, we decided to use the data-parcelling method to increase the stability of the model factor structure (Little et al., 2002). Compared with item-level data, models based on parcelled data have several advantages: notably, they are more parsimonious, there is less correlation of residuals and there are fewer sources of sampling error (Little et al., 2002; MacCallum et al., 1999). To create the respective parcels for our structural equation model, we followed the recommendations of Kishton and 
Widaman (1994) for multidimensional item sets and built the parcels by using the first-order factors of transformational leadership and follower dependency as grouping criteria (e.g. the first parcel of transformational leadership reflected the component of attributed idealized influence).

\section{Results}

Table 4 shows means, standard deviations and intercorrelations of the variables. Transformational leadership was significantly and positively correlated with both followers' dependency and followers' creativity. As expected, followers' dependency and followers' creativity showed significant and negative intercorrelation. Before we tested our hypotheses, we conducted a Harmon's single-factor test (Podsakoff and Organ, 1986) to address the issue of common method variance. This test revealed a poor model fit $\left(\chi^{2} / \mathrm{df}=9.409\right.$, $\mathrm{CFI}=0.605$, RMSEA $=0.142$ ), indicating that there is not one general method factor that explains the majority of covariance among the variables.

The value and the fit indices produced by an AMOS 18 estimation of the parcelled model suggested that the model fits the data well: the $\chi^{2}$ value $\left(\chi^{2}=451.036, \mathrm{p}<0.01\right)$ was significant; yet, this may be attributable to the large sample size. The $\chi^{2} / \mathrm{df}$ value showed a satisfying value, being below $3\left(\chi^{2} / \mathrm{df}=2.438\right)$. The CFI fit index was substantially above the suggested 0.90 cutoff $(\mathrm{CFI}=0.926)$ and the RMSEA indicated an acceptable level of error in the model $(\mathrm{RMSEA}=0.059)$ (see Bentler, 1980, 1990; Kline, 1998). All the factor loadings of the transformational leadership parcels, the follower dependency parcels and the follower creativity items were statistically significant $(\mathrm{p}<0.05)$. As validation, we also analysed the item-level model and still found acceptable fit values (with $\chi^{2} / \mathrm{df}<3, \mathrm{CFI}>0.90$ and RMSEA < 0.08).

Regarding the path loadings of our parcelled model (see Table 5), the results show a positive and significant direct effect of transformational leadership on followers' creativity $(\beta=0.208$; $\mathrm{p}<0.01)$ as well as a positive and significant total effect $(\beta=0.117, \quad p<0.01)$, thus supporting Hypothesis 1. As predicted, transformational leadership also had a positive and significant direct effect on follower dependency $(\beta=0.324$; $\mathrm{p}<0.01$ ) which in turn had a negative and significant direct effect on follower creativity $(\beta=-0.282 ; p<0.01)$. Thus, Hypotheses 2 and 3 could also be confirmed. Followers' team longevity was negatively related to creativity $(\beta=-0.120$; $p<0.05)$. In order to test whether the difference between the positive direct and total effect of transformational leadership on individual creativity is significant, we conducted a Sobel test (Sobel, 1982). As expected, the results showed a significant test statistic (Sobel test statistic $=2.030$;

Table 4. Descriptive statistics and intercorrelations

\begin{tabular}{|c|c|c|c|c|c|c|}
\hline Variable & Mean & SD & 1 & 2 & 3 & 4 \\
\hline 1. Followers' team longevity & 30.965 & 38.810 & - & & & \\
\hline 2. Transformational leadership & 6.051 & 1.039 & 0.010 & - & & \\
\hline 3. Followers' dependency & 2.804 & 0.668 & 0.014 & $0.245^{* *}$ & - & \\
\hline 4. Followers' creativity & 5.193 & 0.841 & -0.102 & $0.109 *$ & $-0.170 * *$ & - \\
\hline
\end{tabular}

$* * * \mathrm{p}<0.001 ; * * \mathrm{p}<0.01 ; * \mathrm{p}<0.05$

Table 5. Structural equation modelling

\begin{tabular}{|c|c|c|c|}
\hline Independent variable & Direct effect & Indirect effect & Total effect \\
\hline \multicolumn{4}{|c|}{ Dependent variable followers' dependency } \\
\hline Transformational leadership & $0.324 * *$ & & \\
\hline \multicolumn{4}{|c|}{ Dependent variable followers' creativity } \\
\hline Followers' dependency & $-0.282 * * *$ & & \\
\hline Transformational leadership & $0.208 * *$ & -0.091 & $0.117 *$ \\
\hline
\end{tabular}

$* * \mathrm{p}<0.01 ; * \mathrm{p}<0.05$. 


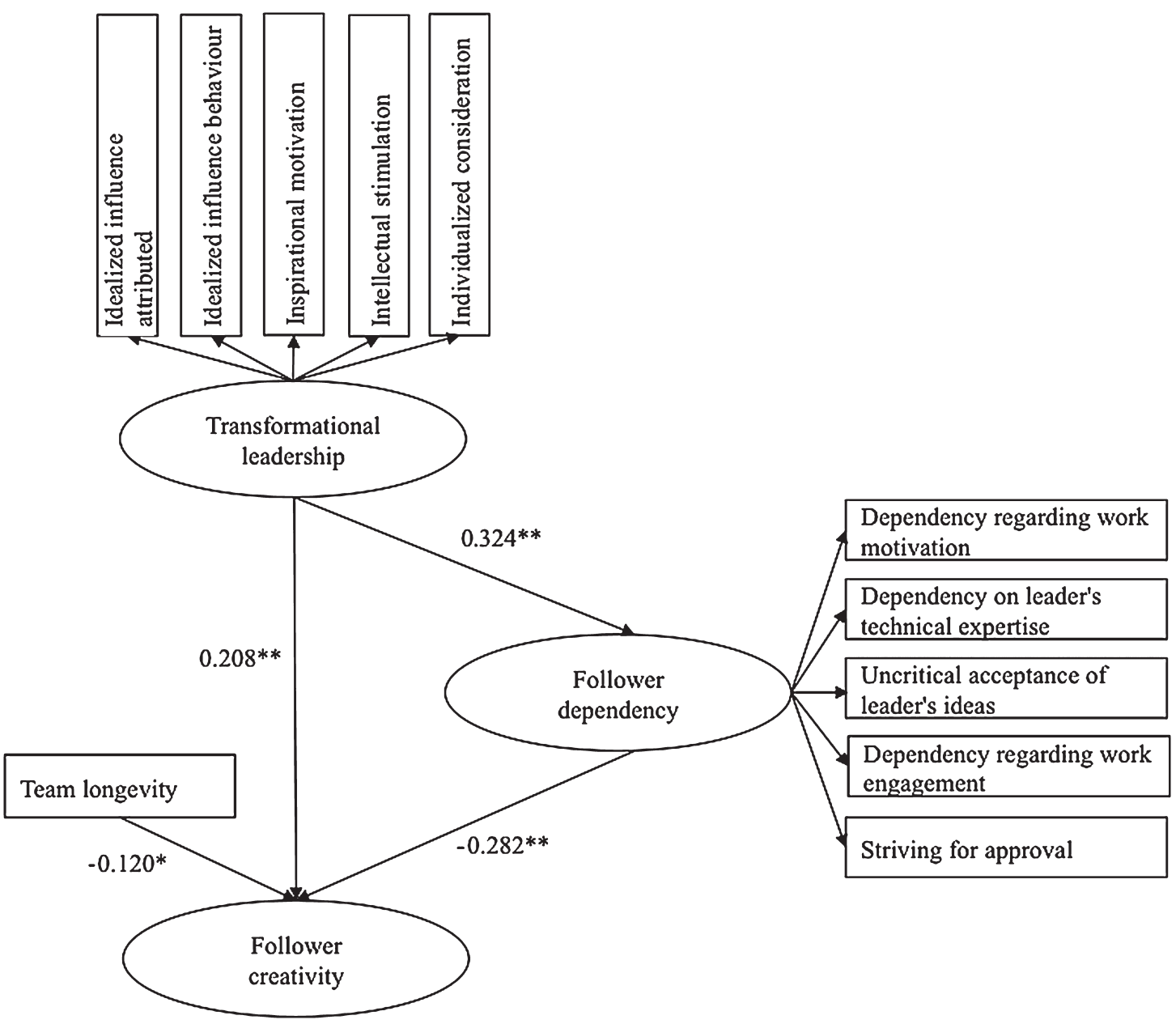

Figure 2. Results of structural equation modelling (illustrated at the parcel level)

$\mathrm{p}<0.05$ ), hence supporting Hypothesis 4 . Figure 2 shows the results of the structural equation model at the parcel level.

\section{Discussion}

Although the leadership literature has repeatedly touched upon the negative side effects of charismatic and transformational leadership (e.g. Conger, 1990; Conger and Kanungo, 1998; Yukl, 1999), there has been little attempt to empirically analyse the subject matter. Addressing this research gap, the present study examined the relationship between transformational leadership and followers' creativity, taking into account follow- ers' dependency on the leader as a negative side effect of transformational leadership. More precisely, in addition to promoting followers' creativity, transformational leadership was expected to simultaneously increase followers' dependency which in turn was assumed to be negatively related to followers' creativity. Using a sample of 416 R\&D employees, we found support for our hypotheses. The results showed a positive link between transformational leadership and followers' creativity which was significantly reduced by transformational leadership's negative relationship via followers' dependency on the leader. The overall relationship between transformational leadership and followers' creativity still remained positive. 
This positive relationship between transformational leadership and followers' creativity is consistent with the findings of Shin and Zhou (2003) and Gong, Huang and Farh (2009). Extending the current literature on transformational leadership and creativity, we analysed the relationship between transformational leadership and creativity and empirically identified follower dependency as a mediating mechanism in the transformational leadership-creativity link. Our findings thus empirically support Basu and Green's (1997) argumentation that transformational leadership is negatively associated with follower creativity via follower dependency.

Surprisingly, there is only one empirical study which addressed the negative side of transformational leadership and examined follower dependency. In a study in the banking sector, Kark, Shamir and Chen (2003) predicted and confirmed that transformational leadership increases followers' dependency. The present study showed that this relationship also holds true for the $R \& D$ sector and went one step further by analysing the relationship between followers' dependency and followers' creativity.

Some authors differentiated between an ethical and unethical form of transformational and charismatic leadership (Bass, 1998; Bass and Steidlmeier, 1999; Howell, 1988; Howell and Avolio, 1992) and argued that it is the unethical form of transformational and charismatic leadership that may trigger followers' dependency (Bass, 1998; Howell, 1988). However, as we assessed transformational leadership using the MLQ which was explicitly designed to measure the ethical form of transformational leadership - the so-called authentic transformational leadership (de Vries, Roe and Taillieu, 1999, 2002) - the present results suggest that followers' dependency also tends to increase under authentic transformational leadership.

\section{Limitations}

Despite these contributions, the present study has some limitations. First, followers' creativity was measured via self-assessment and thus may imply a self-serving bias (see Edwards, 1957). Unfortunately, it was not possible to obtain leader ratings on followers' creativity. Facing strict time constraints and high opportunity costs, the surveyed organizations were unwilling to allow managers to rate the creativity of each follower. However, empirical research indicated considerable overlapping between self-assessment and leaders' assessment of different outcome variables (Fox and Dinur, 1988; Harris and Schaubroeck, 1988). Second, by using only followers' ratings, there is a risk of method variance. However, the results from Harmon's single-factor test indicated that common method effects are not likely to pose a pervasive problem in this study. Third, our sample was conducted in the R\&D sector. The generalization of our findings may therefore be limited regarding the organizational background.

\section{Implications for research}

On the basis of the results of the present study, we suggest further research on negative side effects of transformational and charismatic leadership in order to obtain a more realistic picture and a more sophisticated understanding of how these leadership styles work and under what premises they are appropriate to apply. First, it seems to be of importance to specify the moderators in the relationship between transformational leadership and followers' dependency. Knowledge of the moderators would allow separating the negative side effects from the positive ones and thus make transformational leadership an even more powerful lever for stimulating creativity. In particular, followers' characteristics such as a need for leadership (de Vries, Roe and Taillieu, 2002) or the 'Big Five' personality traits (see Costa and McCrae, 1988) should be investigated as possible moderators. Furthermore, followers' individual differences regarding the affiliation motive and their associated need for attachment and belonging may also play a role in the relationship between transformational leadership and follower dependency (McClelland, 1987). Second, future research should analyse the consequences of followers' dependency on additional outcome variables such as followers' performance or satisfaction. Presumably, the effects of followers' dependency differ according to the outcome variable under study. Third, further research should identify and empirically examine other negative side effects of transformational leadership. For instance, Conger (1990) noted that transformational leaders may increase group think. Fourth, in light of the above limitations, we recommend replicating this study with manager ratings of 
followers' creativity or with creativity tests, using employees of different nationalities and working in a wide range of sectors.

\section{Managerial implications}

Regarding organizational creativity management, our results indicate that organizations can facilitate their employees' creativity by enhancing managers' transformational leadership style. Previous research provided evidence that transformational leadership can be developed in focused training programmes (Barling, Weber and Kelloway, 1996; Dvir et al., 2002). Hence, organizations placing strong emphasis on creativity and innovative outcomes should implement transformational leadership courses in which managers can learn how to effectively encourage, motivate and intellectually stimulate their followers. In particular, upper-level managers in the R\&D sector are often recruited or promoted because of excellent technical expertise but may lack the specific leadership skills for successfully tapping the full creative potential of their followers and are therefore likely to greatly benefit from transformational leadership trainings.

However, our findings also indicate that transformational leadership may raise followers' dependency on the leader. From a normativeethical perspective, transformational leadership thus seems to challenge the followers' personal development and their right of self-determination (Bandura, 2001). In addition, from a pragmatic perspective, follower dependency can reduce the overall possible level of individual creativity. Consequently, for both normative and pragmatic reasons, any transformational leadership training (e.g. the training programmes developed by Avolio, 1999) should not be indiscriminately implemented but should be supplemented with education programmes on the possible negative side effects of transformational leadership, particularly with reference to the risk of increased follower attachment and dependency.

\section{Conclusion}

The present study addresses an important topic that has been neglected in leadership research: i.e. the negative side of transformational leadership. We contribute to the current literature on leader- ship and creativity (1) by examining the link between transformational leadership and followers' creativity in the R\&D sector, (2) by studying follower dependency on the leader as a negative aspect of transformational leadership and (3) by revealing the complexity of parallel positive and negative effects of transformational leadership on followers' creativity.

\section{References}

Amabile, T. M. (1988). 'A model of creativity and innovation in organizations', Research in Organizational Behavior, 10, pp. $123-167$.

Anderson, N. R., C. K. W. de Dreu and B. A. Nijstad (2004) 'The routinization of innovation research: a constructively critical review of the state-of-the-science', Journal of Organizational Behavior, 25, pp. 147-173.

Antonakis, J. and R. J. House (2002). 'The full-range leadership theory: the way forward'. In B. J. Avolio and F. J. Yammarino (eds), Transformational and Charismatic Leadership: The Road Ahead, pp. 3-33. Amsterdam: JAI.

Avolio, B. J. (1994). 'Total quality and leadership'. In B. M Bass and B. J. Avolio (eds), Improving Organizational Effectiveness Through Transformational Leadership, pp. 121-145. Thousand Oaks, CA: Sage.

Avolio, B. J. (1999). Full Leadership Development. Thousand Oaks, CA: Sage.

Avolio, B. J. and B. M. Bass (1988). 'Transformational leadership, charisma, and beyond'. In J. G. Hunt, B. R. Baliga, H P. Dachler and C. A. Schriesheim (eds), Emerging Leadership Vistas, pp. 29-49. Lexington, MA: Lexington Books.

Avolio, B. J., B. M. Bass and D. I. Jung (1999). 'Re-examining the components of transformational and transactional leadership using the Multifactor Leadership Questionnaire', Journal of Occupational and Organizational Psychology, 72, pp. 441-462.

Bandura, A. (1998). Self-Efficacy: The Exercise of Control. New York: Freeman.

Bandura, A. (2001). 'Social cognitive theory: an agentic perspective', Annual Review of Psychology, 52, pp. 1-26.

Barling, J., T. Weber and E. K. Kelloway (1996). 'Effects of transformational leadership training on attitudinal and financial outcomes: a field experiment', Journal of Applied Psychology, 81, pp. 827-832.

Bass, B. M. (1985). Leadership and Performance Beyond Expectations. New York: Free Press.

Bass, B. M. (1998). Transformational Leadership: Industry, Military, and Educational Impact. Mahwah, NJ: Lawrence Erlbaum.

Bass, B. M. and B. J. Avolio (1994). Improving Organizational Effectiveness Through Transformational Leadership. Thousand Oaks, CA: Sage.

Bass, B. M. and B. J. Avolio (1995). MLQ Multifactor Leadership Questionnaire. Technical report. Redwood City, CA: Mind Garden.

Bass, B. M. and R. E. Riggio (2006). Transformational Leadership. Mahwah, NJ: Lawrence Erlbaum. 
Bass, B. M. and P. Steidlmeier (1999). 'Ethics, character, and authentic transformational leadership behavior', Leadership Quarterly, 10, pp. 181-217.

Basu, R. and S. G. Green (1997). 'Leader-member exchange and transformational leadership: an empirical examination of innovative behaviors in leader-member dyads', Journal of Applied Social Psychology, 27, pp. 477-499.

Bentler, P. M. (1980). 'Mutivariate analysis with latent variables: causal modeling', Annual Review of Psychology, 31, pp. 419-456.

Bentler, P. M. (1990). 'Comparative fit indexes in structural models', Psychological Bulletin, 107, pp. 238-246.

Beyer, J. M. (1999). 'Two approaches to staying charismatic leadership: competing or complementary?', Leadership Quarterly, 10, pp. 575-588.

Birtchnell, J. (1988). 'Defining dependence', British Journal of Medical Psychology, 61, pp. 111-123.

Brislin, R. W. (1986). 'The wording and translation of research instruments'. In W. J. Lonner and J. W. Berry (eds), Field Methods in Cross-Cultural Research, pp. 137-164. Beverly Hills, CA: Sage.

Bryman, A. (1992). Charisma and Leadership in Organizations. London: Sage.

Burns, J. M. (1978). Leadership. New York: Harper and Row.

Carlson, D. S., K. M. Kacmar and L. J. Williams (2000). 'Construction and initial validation of a multidimensional measure of work-family conflict', Journal of Vocational Behavior, 56, pp. 249-276.

Cascio, W. F. (1995). 'Whither industrial and organizational psychology in a changing world of work?', American Psychologist, 50, pp. 928-939.

Chusmir, L. H. and C. S. Koberg (1986). 'Creativity differences among managers', Journal of Vocational Behavior, 29, pp. 240-253.

Conger, J. A. (1990). 'The dark side of leadership', Organizational Dynamics, 19, pp. 44-55.

Conger, J. A. (1999). 'Charismatic and transformational leadership in organizations: an insider's perspective on these developing streams of research', Leadership Quarterly, 10, pp. $145-170$.

Conger, J. A. and R. N. Kanungo (1992). 'Perceived behavioural attributes of charismatic leadership', Canadian Journal of Behavioural Science, 24, pp. 86-102.

Conger, J. A. and R. N. Kanungo (1998). Charismatic Leadership in Organizations. Thousand Oaks, CA: Sage.

Costa, P. T. J. and R. R. McCrae (1988). 'From catalogue to classification: Murray's needs and the five-factor model', Journal of Personality and Social Psychology, 55, pp. 258-265.

DeGroot, T., D. S. Kiker and T. C. Cross (2000). 'A metaanalysis to review organizational outcomes related to charismatic leadership', Canadian Journal of Administrative Sciences, 17, pp. 356-371.

Dumdum, U. R., K. B. Lowe and B. J. Avolio (2002). 'A metaanalysis of transformational and transactional leadership correlates of effectiveness and satisfaction: an update and extension'. In B. J. Avolio and F. J. Yammarino (eds), Transformational and Charismatic Leadership: The Road Ahead, pp. 35-66. Amsterdam: JAI.

Dvir, T., D. Eden, B. J. Avolio and B. Shamir (2002). 'Impact of transformational leadership on follower development and performance: a field experiment', Academy of Management, 45, pp. 735-745.
Edwards, A. L. (1957). The Social Desirability Variable in Personality Assessment and Research. Westport, CN: Greenwood.

Felfe, J. (2006). 'Validierung einer deutschen Version des "Multifactor Leadership Questionnaire" (MLQ Form $5 \times$ Short) von Bass und Avolio (1995)', Zeitschrift für Arbeits- und Organisationspsychologie, 50, pp. 61-78.

Fox, S. and Y. Dinur (1988). 'Validity of self-assessment: a field evaluation', Personnel Psychology, 41, pp. 581-592.

García-Morales, V. J., F. J. Lloréns-Montes and A. J. Verdú-Jover (2008). 'The effects of transformational leadership on organizational performance through knowledge and innovation', British Journal of Management, 19, pp. 299 319.

Gardner, W. L. and B. J. Avolio (1998). 'The charismatic relationship: a dramaturgic perspective', Academy of Management Review, 23, pp. 32-58.

Gebert, D. (2002). Führung und Innovation. Stuttgart: Kohlhammer.

Gong, Y., J. Huang and J. Farh (2009). 'Employee learning orientation, transformational leadership, and employee creativity: the mediating role of employee creative self-efficacy', Academy of Management Journal, 52, pp. 765-778.

Guttman, L. (1954). 'Some necessary conditions for common factor analysis', Psychometrika, 19, pp. 149-161.

Harris, M. M. and J. Schaubroeck (1988). 'A meta-analysis of self-supervisor, self-peer, and peer-supervisor ratings', Personnel Psychology, 41, pp. 43-62.

den Hartog, D. N., R. J. House, P. J. Hanges, S. A. Ruiz-Quintanilla and P. W. Dorfman (1999). 'Culture specific and cross-culturally generalizable implicit leadership theories: are attributes of charismatic/transformational leadership universally endorsed?', Leadership Quarterly, 10, pp. 219256

Hogan, R., R. Raskin and D. Fazzini (1990). 'The dark side of charisma'. In K. E. Clark and M. B. Clark (eds), Measures of Leadership, pp. 343-354. West Orange, NJ: Leadership Library of America.

House, R. J. and J. M. Howell (1992). 'Personality and charismatic leadership', Leadership Quarterly, 3, pp. 81-108.

Howell, J. M. (1988). 'Two faces of charisma: socialized and personalized leadership in organizations'. In J. A. Conger and R. N. Kanungo (eds), Charismatic Leadership: The Elusive Factor in Organizational Effectiveness. San Francisco, CA: Jossey-Bass.

Howell, J. M. and B. J. Avolio (1992). 'The ethics of charismatic leadership: submission or liberation', Academy of Management Executive, 6, pp. 43-54.

Howell, J. M. and C. A. Higgins (1990). 'Champions of technological innovation', Administrative Science Quarterly, 35, pp. 317-341.

Jaussi, K. S. and S. D. Dionne (2003). 'Leading for creativity: the role of unconventional leader behavior', Leadership Quarterly, 14, pp. 475-498.

Judge, T. A. and R. F. Piccolo (2004). 'Transformational and transactional leadership: a meta-analytic test of their relative validity', Journal of Applied Psychology, 89, pp. 755768.

Jung, D. I., C. Chow and A. Wu (2003). 'The role of transformational leadership in enhancing organizational innovation: hypotheses and some preliminary findings', Leadership Quarterly, 14, pp. 525-544. 
Kark, R. and B. Shamir (2002). 'The dual effect of transformational leadership: priming relational and collective selves and further effects on followers'. In B. J. Avolio and F. J. Yammarino (eds.), Transformational and Charismatic Leadership: The Road Ahead, pp. 67-91. Amsterdam: JAI.

Kark, R., B. Shamir and G. Chen (2003). 'The two faces of transformational leadership: empowerment and dependency', Journal of Applied Psychology, 88, pp. 246-255.

Katz, R. (1982). 'The effects of group longevity on project communication and performance', Administrative Science Quarterly, 27, pp. 81-104.

Kets de Vries, M. F. R. (1988). 'Prisoners of leadership', Human Relations, 41, pp. 261-280.

Kets de Vries, M. F. R. and D. Miller (1984). The Neurotic Organization: Diagnosing and Changing Counterproductive Styles of Management. San Francisco, CA: Jossey-Bass.

Kirkpatrick, S. A. and E. A. Locke (1996). 'Direct and indirect effects of three core charismatic leadership components on performance and attitudes', Journal of Applied Psychology, 81, pp. $36-51$.

Kishton, J. M. and K. F. Widaman (1994). 'Unidimensional versus domain representative parceling of questionnaire items: an empirical example', Educational and Psychological Measurement, 54, pp. 757-765.

Kline, R. B. (1998). Principles and Practices of Structural Equation Modeling. New York: Guilford Press.

Little, T. D., W. A. Cunningham, G. Shahar and K. F. Widaman (2002). 'To parcel or not to parcel: exploring the question, weighting the merits', Structural Equation Modeling, 9, pp. 151-173

Lowe, K. B. and W. L. Gardner (2000). 'Ten years of The Leadership Quarterly: contributions and challenges for the future', Leadership Quarterly, 11, pp. 459-514.

Lowe, K. B., K. G. Kroeck and N. Sivasubramaniam (1996). 'Effectiveness correlates of transformational and transactional leadership: a meta-analytic review of the MLQ literature', Leadership Quarterly, 7, pp. 385-425.

MacCallum, R. C., K. F. Widaman, S. Zhang and S. Hong (1999). 'Sample size in factor analysis', Psychological Methods, 4, pp. 84-99.

McClelland, D. C. (1987). Human Motivation. Cambridge: Cambridge University Press.

Mullen, B., T. Anthony, E. Salas and J. E. Driskell (1994). 'Group cohesiveness and quality of decision making: an integration of tests of the groupthink hypothesis', Small Group Research, 25, pp. 189-204.

Patterson, C. E. P., J. B. Fuller K. Hester and D. Y. Stringer (1995). 'A meta-analytic examination of leadership style and selected compliance outcomes'. Paper presented at the 10th Annual Conference of the Society for Industrial and Organizational Psychology, Orlando, FL.

Paulus, P. B. (2002). 'Different ponds for different fish: a contrasting perspective on team innovation', Applied Psychology: An International Review, 51, pp. 394-399.

Pillai, R. and E. A. Williams (2004). 'Transformational leadership, self-efficacy, group cohesiveness, commitment, and performance', Journal of Organizational Change Management, 17, pp. 144-159.

Pirola-Merlo, A. and L. Mann (2004). 'The relationship between individual creativity and team creativity: aggregating across people and time', Journal of Organizational Behavior, 25, pp. 235-257.

Podsakoff, N. P. and D. W. Organ (1986). 'Self-reports in organizational research: problems and prospects', Journal of Management, 12, pp. 531-544.

Popper, M. and O. Mayseless (2003). 'Back to basics: applying a parenting perspective to transformational leadership', Leadership Quarterly, 14, pp. 41-65.

Rank, J., V. L. Pace and M. Frese (2004). 'Three avenues for future research on creativity, innovation, and initiative', Applied Psychology: An International Review, 53, pp. 518528.

Shamir, B. (1991). 'The charismatic relationship: alternative explanations and predictions', Leadership Quarterly, 2, pp. 81-104.

Shamir, B., R. J. House and M. B. Arthur (1993). 'The motivational effects of charismatic leadership: a self-concept based theory', Organization Science, 4, pp. 577-594.

Shin, S. J. and J. Zhou (2003). 'Transformational leadership, conservation, and creativity: evidence from Korea', Academy of Management Journal, 46, pp. 703-714.

Sobel, M. E. (1982). 'Asymptotic confidence intervals for indirect effects in structural equation models'. In S. Leinhardt (ed.), Sociological Methodology, pp. 290-312. Washington, DC: American Sociological Association.

Steyrer, J. (1999). 'Charisma in Organisationen - zum Stand der Theorienbildung und empirischen Forschung', Managementforschung, 9, pp. 143-197.

Tourish, D., R. Craig and J. Amernic (2010). 'Transformational leadership education and agency perspectives in business school pedagogy: a marriage of inconvenience?', British Journal of Management, 21 (Suppl. 1), pp. 40-59.

de Vries, R. E., R. A. Roe and T. C. B. Taillieu (1999). 'On charisma and need for leadership', European Journal of Work and Organizational Psychology, 8, pp. 109-133.

de Vries, R. E., R. A. Roe and T. C. B. Taillieu (2002). 'Need for leadership as a moderator of the relationships between leadership and individual outcomes', Leadership Quarterly, 13, pp. 121-137.

Waldman, D. A. and B. M. Bass (1991). 'Transformational leadership at different phases of the innovation process', Journal of High Technology Management Research, 2, pp. 169-180.

Wang, P. and J. C. Rode (2010). 'Transformational leadership and follower creativity: the moderating effects of identification with leader and organizational climate', Human Relations, 63, pp. 1105-1128.

West, M. A. (2003). 'Innovation implementation in work teams'. In P. B. Paulus and B. A. Nijstad (eds), Group Creativity: Innovation Through Collaboration, pp. 245-276. Oxford: Oxford University Press.

Yukl, G. (1998). Leadership in Organizations. Upper Saddle River, NJ: Prentice-Hall.

Yukl, G. (1999). 'An evaluation of conceptual weaknesses in transformational and charismatic leadership theories', Leadership Quarterly, 10, pp. 285-305.

Zhou, J. and J. M. George (2001). 'When job dissatisfaction leads to creativity: encouraging the expression of voice', Academy of Management Journal, 44, pp. 682696. 
Silke A. Eisenbeiß is a Post-Doctoral Research Fellow of the Excellence Initiative at the Department of Organizational and Economic Psychology, LMU Munich, Germany. Within her research, she focuses on examining leadership, business ethics, creativity and intercultural management. Her work has been published in the Journal of Applied Psychology, Creativity and Innovation Management and

Journal of Leadership and Organizational Studies.

Sabine Boerner holds the Chair of Management, especially Strategy and Leadership, at the Department of Politics and Management, University of Konstanz, Germany. Her research interests centre on leadership, cooperation in organizational groups and innovation. Her work has been published in leading journals, including Journal of Applied Psychology, Creativity and Innovation Management, Journal of Entrepreneurship and Innovation Management, Journal of Leadership and Organizational Studies and Human Resource Development International. 